\title{
Methodology for determination of the priority directions for the city's industrial development
}

\author{
Ivan Palatkin ${ }^{1, *}$, Alexander Pavlov ${ }^{2}$, Alexander Kudryavtsev ${ }^{2}$ \\ ${ }^{1}$ Moscow state University of technology and management. K. G. Razumovsky (Penza branch), \\ Gagarin street, 11A/12, Penza, 440039, Russia \\ ${ }^{2}$ Penza State Technological University, 440039, pr. Baydukova/Gagarin street, 1a/ 11, Penza, 440039, \\ Russia
}

\begin{abstract}
In the face of new global challenges, the economic and social significance of territorial problems in the Russian Federation has received a different, extremely acute meaning. The crisis and shortage of the budgets of most of the municipal formations in the country predetermine the shift of problems of ensuring sustainable development of urban areas from theory to practice. The purpose of this study is to develop a methodology for determination of the priority directions for the city's industrial development. The paper analyzes the principles of sustainable development in the field of urban planning and spatial planning, outlines the mechanisms for stimulating economic growth in cities and the ways to determine the priority directions of the city's industrial development. The authors carried out a practical testing of the proposed methodology on the example of the city of Penza. Recommendations for a more complete use of the potential of the machine-building industry are developed.
\end{abstract}

\section{Introduction}

The observed increase in disproportions in the social and economic development of municipal facilities in Russia under the impact of market reforms leads to inefficient use of the spatial and resource potential and rightly relates to the most significant challenges for society and the state in the "Strategy for Scientific and Technological Development of the Russian Federation".

The mechanism of market competition divided the territory depending on the degree of their adaptability to the market, the availability of resources, the structure of the economy, the mentality of the population and authorities. With the entry into force of Federal Law No.131 "On the general principles of the organization of local self-government", cities with a huge economic potential are the clear leaders of municipal development. Modern territories from a simple place of economic actions turn into sellers of goods and services, i.e. equal participants in the market. In this connection, the issue of choosing priority industries capable to become "growth points" of the urban economy becomes relevant [1].

At the same time, the domestic practice of analyzing the level of territorial development, associated with the names of Abalkin L.I., Glazyev S.Yu., Granberg A.G.,

*Corresponding author: ivpalatkin@bk.ru 
Kistanov V.V., Leksin V.N., Shvetsova A.N., etc., does not emphasize the study of regional aspects of the spatial development strategy of social and economic systems of municipal facilities, taking into account the implementation in Russia of the concept of sustainable development.

In the absence of a mechanism for identifying promising industries of the urban economy that can raise the level of social and economic welfare of the territory, there is a need to develop a methodology for determination of the priority directions of the city's industrial development, presented as an objective of the study [2].

\section{Materials and methods}

The twentieth century, which became a period of unprecedented growth of cities and settlement systems, revealed the need of mankind to develop and implement the principles of sustainable development in the field of urban planning and spatial planning, including:

1) the creation of a rational number of floors in residential facilities (no higher than 5 floors) in new settlements or neighborhoods of cities; taking into account the convenient transport infrastructure in the planning decisions; accessibility of administrative, business and shopping centers, social institutions [3].

2) the creation of transport infrastructure, taking into account the most environmentally acceptable transport, and also taking into account the possibilities of using local sources of renewable energy in each district of the city.

3 ) the creation of a system for separate collection of municipal solid waste with maximum recycling of secondary materials, development of convenient schemes for the composting of household waste.

4) the creation of social infrastructure facilities necessary for the educational, cultural and spiritual development of a healthy, creatively active society [4].

5 ) the development of a full-fledged local economy within the priority areas of business, ensuring diversity, self-repayment and self-sufficiency of the territories. Compliance with this principle creates a basis for achieving sustainable development of cities, i.e. the implementation of such changes in which the exploitation of natural resources, the direction of investment, the orientation of scientific and technological progress, personal development and institutional reforms are coordinated with one another and strengthen the present and future potential to meet human needs and aspirations.

The economy of each city consists of 3 main sectors - the basic sector, the service sector (auxiliary industries that provide life support for people) and the household sector. The basic sector bears the city-forming functions. Its enterprises specialize in the production and export of industrial goods and services outside the urban economy. The economic and territorial structure of a city depends on the specifics of the development and specialization of the basic and service sectors. Generally, the development of base production leads to the occurrence of production support services. In its turn, the expansion of base production leads to the growth of employment and an increase in the number of people in the household sector [5].

Two mechanisms for stimulating economic growth in cities need to be highlighted.

The first approach is acceptable in conditions of incomplete use by the city of its own economic resources. When the production capacities of existing enterprises are mainly unloaded, when unemployment is high, and tax revenues to the budget are reduced because of a drop in production and a decrease in the population's money income, the government is forced to look for ways to make resources "work again".

The second approach is acceptable in the case when the available production capacities are fully engaged and the further development of the city economy is associated with the 
increase of its competitiveness, structural reorganization, and the increase in production efficiency through the use of organizational innovations. [6]

Economic practice has developed several ways to determine the priority directions of the city's industrial development.

1. By the share of the industry in the total volume of output produced in the economy of the city for a certain period.

The most promising for development are the sectors that have a greater share in the volume of output. The disadvantage of this method is the impossibility of accounting for the costs of each industry. This can lead to the fact that industries that are not typical for this region, having a small volume of output with a large cost value, will be in a better position in comparison with the other industries.

2. By the share of unprofitable enterprises in the industry.

This method is based on the comparison of the total number of enterprises operating in each industry of the city with the number of unprofitable enterprises in this industry. It is accepted that the higher the share of unprofitable enterprises, the more unpromising this industry is for investing in its development. Promising industries are the industries that have a lower indicator of unprofitable enterprises than the overall indicator for all enterprises of the city.

3. By the monetary profits received by the industries.

This method is similar to the previous one, only here absolute indicator is taken as an evaluation criterion, not relative. The application of this method is based on the proposition that an industry that has a large volume of output with a low profitability in real monetary terms can bring a larger amount of revenues to the city budget than a sector that has a small volume of output with a large profitability. Accordingly, industries with a large monetary profit are more promising.

4. The method of strategic positioning of industries.

Strategic positioning is based on the method developed by The Boston Consulting Group. This method of assessing market positions within a two-dimensional matrix can be used to formulate the economic policy of the city and select priority directions for industrial development. Two criteria are used as matrix variable parameters: the sales market growth rates (production index) and the investment activity of the industries (index of investments).

The index of the physical volume of industrial production, calculated by the chain method for a certain period, fully indicates how "energetically" the industries used the factor of increasing demand for growth in sales and business.

The second indicator - the index of physical volume of investments in fixed capital shows how actively the enterprises used the investment resources for development, renovation of fixed assets and achievement of the set goals.

At the city level, it is necessary to create conditions for groups of industries located in the first and third quadrants of the matrix (successful industries and accumulation sectors) to receive sustainable incentives to move to the second quadrant intended for the leader industries (Figure 1).

\begin{tabular}{|c|c|c|}
\hline \multicolumn{3}{|c|}{ Industrial production index } \\
\hline high & I & II \\
\hline low & IV & III \\
\hline & low & high \\
\hline \multicolumn{3}{|c|}{ Index of total volume of investments } \\
\hline
\end{tabular}

Fig. 1. Positioning of the city's economy. 
5. The use of a complex matrix "The attractiveness of the industry - the competitiveness of enterprises of the city".

Criteria for determining the long-term attractiveness of the industry include: the size and rate of the market growth; severity of competition; need for capital; trends in investment in the industry; occurring threats and opportunities in the industry; actual and projected profit in the industry; economic factors.

The criteria for the competitiveness of city enterprises include: the share of an enterprise in the market; ability to compete with the leading enterprises of the industry in terms of product quality and service; rate of return in comparison with competitors; technological capabilities; quality of management.

Enterprises belonging to groups 1, 2, 4 have high competitiveness and work in the industries with high and moderate attractiveness. From an investor's point of view, these enterprises have the highest development potential and the lowest investment risk among the groups under consideration. The industries of quadrants $6,8,9$ have the reduced priority of investment and development (Figure 2).

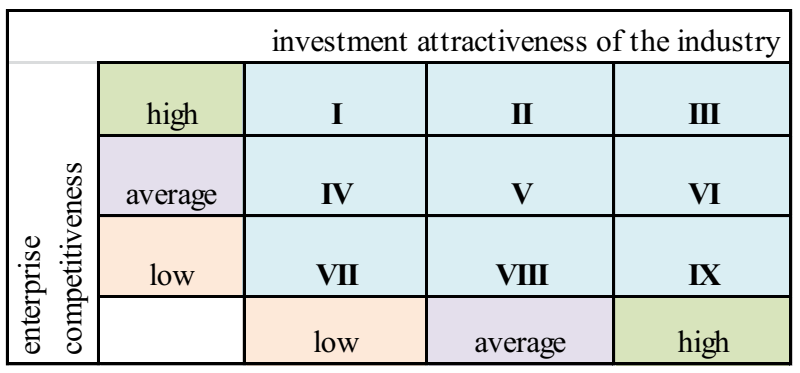

Fig. 2. Matrix "The attractiveness of the industry - the competitiveness of enterprises of the city".

Therefore, the analysis of the considered methods allows identifying the priority directions for investment in the city's industrial development. In order to reveal the practical importance of the proposed methods, we will carry out further study using the example of the city of Penza (population of 524.6 thousand people) located in the center of the European part of Russia [7].

\section{Results}

The study of the social and economic situation in the city of Penza on the basis of SWOT analysis made it possible to identify the following strengths: favourable transport and geographical location; retained and developing system of higher and secondary technical and humanitarian education; proximity to the largest regional markets in Russia; an acceptable quality of life in the city; effective and competent city administration interacting well with the city authorities; availability of free land resources; food cluster developed and evaluated by external investors and partners; prospect of growth in woodworking and furniture production; retained competence in the production of instrumentation and information technology.

The following should be noted as weaknesses: the city's weakly diversified business portfolio; jobs are mainly concentrated in budget-dependent industrial sectors; the high degree of dependence of some industries on a limited number of state consumers (Russian Railways, Rosatom, Ministry of Defense, etc.); low quality of the roadway network; the weak development of the credit and financial sector; the small size of the domestic consumer market (by the number and income of the population); the territorial 
neighborhood that win over to its side the best personnel and investors; limited opportunities for choosing the work and career; energy shortage.

One of the opportunities for the city can be an inflow of investments into industrial production on the territory of Russia as a whole, which will facilitate the implementation of restructuring, the solution of the problems of reconstruction of existing production facilities, the upgrade of the equipment of technology park, the development of infrastructure, and the creation of new jobs.

Penza concentrates more than $50 \%$ of the institutional, financial and consumer potential of the Penza region, which provides the city with a common leadership in terms of total investment potential.

Based on the assessment of statistical data, the analysis of various areas of the city's industrial development will be made.

1. By the share of the industry in the total volume of output produced in the city, the most important industry is machine building $-33.2 \%$, which exceeds the share of the next industry (food industry) by $25 \%$.

2. By the share of unprofitable enterprises, the most successful industry is also machine building, where the share of unprofitable enterprises in 2016 was $10 \%$, in the food industry $-12 \%$, in agriculture $-15 \%$.

3. In 2016 the most profitable were the machine-building industry - more than 300 million rubles, and woodworking industry - more than 250 million rubles.

4. The results of the assessment of the main industries according to the methodology presented in Figure 1 show that 3 leading industries (forestry, woodworking and pulp and paper industry; machine building and metalworking; food industry) are positioned in the second quadrant of the matrix. These industries combined high growth rates of the final index of industrial production and the final index of investment in fixed capital. The share of these industries accounts for more than $60 \%$ of the city's production output.

There is one industry in the first quadrant: construction industry. In the industry, there is an increase in sales volumes with a relatively low growth rate of investment in fixed capital. Its development is mainly caused by the external factors: favorable market conditions in the construction market, growth of consumer demand. For successful development of the enterprises of the first quadrant of the matrix, it is necessary to intensify work on attracting market sources of financing [8].

For the energy industry, which is a part of the third quadrant of the matrix, the main thing is to solve the problem of growth by increasing the physical volumes of electricity supplied, and not by increasing the tariffs. Obviously, in the next 2-3 years the industry has a chance for positioning in the second quadrant of the matrix.

Light industry is positioned in the fourth quadrant, having the worst position in the chosen coordinate system.

5. Analysis of the matrix "The attractiveness of the industry - the competitiveness of the enterprises of the city of Penza" showed that among the most prepared for investment productions are: in valve industry - OJSC "Penztyazhpromarmatura"; in the pulp and paper industry - OJSC "Mayak"; in the production of wooden and building structures - CJSC "DERA"; in the production of diesel engines and compressors - OJSC "Penzensky Diesel Plant".

Therefore, the main strategic tasks of the industrial development of the city of Penza are:

- creation of conditions for maintaining high growth rates of industrial production and investment in fixed capital for machine-building industry and metalworking, as well as for woodworking and pulp and paper industry;

- ensuring the flow of investment in the construction materials industry. 


\section{Conclusion}

As can be seen from above, the proposed step-by-step methodology for determination of the priority directions of the industrial development of the urban economy made it possible to identify possible ways of intensifying economic growth for the city of Penza by making better use of the potential, first of all, of the machine-building industry which includes five large segments:

1) Manufacture of equipment and fittings for the chemical industry and oil and gas complex.

2) Manufacture of diesel engines and compressors.

3) Manufacture of automotive components.

4) Agricultural machinery, machinery for process manufacturing and light industry.

5) Instrumentation and radio electronics.

The growth rate of the industrial market, in which central enterprises of the cluster are engaged, exceeds the growth rate of the economy as a whole by $2 \%$. The growth rate of the share of the enterprises under the study corresponds to the growth rate in the sector. The share of output of an industrial cluster in the gross regional product exceeds $5 \%$. That is, the controlling action is an active support and initiation of its development.

To ensure the growth of GRP due to the increase in production volumes at machinebuilding enterprises in the city of Penza, it is necessary to use the "pulling" type of economic development, i.e. to ensure the increase in the demand for products of these enterprises through the development of related industries that are manufacturers of the final product. In this case, there will be a "multiplier effect".

\section{References}

1. Global cities of the future: An interactive map (McKinsey\&Company, 2017) http://www.mckinsey.com

2. The Most Dynamic Cities of 2025 (Foreign Policy, 2012)

3. T. May, B. Perry, Promise, Politics and Possibilities, The Earthscan Science in Society Series (Routledge, 2017)

4. N. Verstina, E. Evseev, MATEC Web Conf., 106 (2017)

5. A.F. Sandvall, E.O. Ahlgren, T. Ekvall, Energy Strategy Reviews 18, 212-223 (2017)

6. S.V. Domnina, E.V. Savoskina, N.V. Shekhova, Procedia Engineering 153, 741-746 (2016)

7. L. Manukhina, I. Ivanova, IOP Conference Series: Earth and Environmental Science 19, 90012166 (2017)

8. S.A. Baronin, K.Y. Kulakov, Journal of Applied Economic Sciences 11(4), 698-708 (2016) 